\title{
The Technical-Economic Analysis of Hot Water Supply Systems for Residential Buildings
}

\author{
Karina Tumanova ${ }^{1}$, Aleksandra Cimbale ${ }^{2}$, \\ ${ }^{1,2}$ Ltd. , Rīgas namu pārvaldnieks”
}

\begin{abstract}
The article presents the measurements of hot water and supplied thermal energy consumption in residential buildings, where alterations in bottom distribution were made. Diagrams of hot water and supplied thermal energy consumption for $1 \mathrm{~m}^{3}$ hot water preparation were constructed, using the aggregated data. The research results show that hot water consumption differs from values offered in Regulations of Building Standard LBN 221-98, but the supplied thermal energy consumption for $1 \mathrm{~m}^{3}$ hot water preparation has considerably decreased.
\end{abstract}

Keywords - Hot water, hot water consumption, efficiency, district heating.

\section{INTRODUCTION}

Hot water supply and heating are two of most important components of comfort. Respectively, it is crucial to provide these services qualitatively, with the lowest possible costs, knowing that currently the paying ability of the apartment owners is low, but a high rate of heat energy is an additional load on consumers. The analysis of the problem helps finding solutions showing how to reduce the costs of hot water preparation, as well as to increase quality keeping existing technical facilities (the local heating unit) that allow the preparation of hot water on site using the energy received from the hot carrier of the district heating system (DH). [2]

Most heat supply systems of the residential houses have been constructed 20 and more years ago. According to the Latvian Construction Standard, the operation term has already expired or is close to the end, which leads to the inability to ensure the required temperature and flow of hot water. [1] It is important to take in account the fact that the heat distribution system has relatively high heat loses, but circulation in the hot water system considerably increases hot water costs during summer periods.

In accordance with the statistics, the heat loses in local hot water supply systems comprise up to $8 \%$ of the average effective heat consumption from the insulated standpipes per hour and up to $25 \%$ - from not-insulated standpipes. The heat loses in the circulation circuit often reach $40-50 \%$ from the overall heat loses of the onward flow. [5,6]

Other completed and available researches prove that heat loses of the system comprise $30 \%$ from the overall heat amount required to prepare hot water. [2]

An additional factor that puts an emphasis on the hot water supply system is the consumption of hot water differentiating from the values provided by the Latvian Construction Standard LBN 221-98 "Internal water pipes and canalization of the building". The actual value is twice less than the indicated. Similar hot water consumption can be noticed in other European countries, where the water consumption per person is 50 liters per day. [4]

The main aim of the present research is to determine how the consumption of heat energy for the preparation of hot water and the amount of hot water changes after the replacement of bottom distribution pipes of the heating system in the residential building.

\section{MATERIALS AND METHODS}

The research covers hot water supply systems in six multistory residential apartment buildings in Riga. All of the observed houses were constructed during 1969-1993 in the districts Ziepniekkalns and Pleskodale. All of them have bottom distribution of the hot water supply system. Buildings are connected to the district heating system of JSC "Rigas siltums".

The bottom distribution system / pipes were replaced almost simultaneously - from February to April 2014. PPR PN20 pipes were used to complete the works. The heat insulation was performed from rock wool with the thickness $30 \mathrm{~mm}$ in all residential houses. Excluding the house in Valdeku Street $60 \mathrm{k}-4$, the individual heating units have a programmed night regimen for hot water (reduction of temperature) - from 0:00 till 5:00 o'clock the parameters of hot water are $+35-+40{ }^{\circ} \mathrm{C}$. Calculations were made and the data reviewed and mapped on diagrams to evaluate the financial profitability of the hot water supply system and its operation in the researched houses.

Several scientific methods were used during the research. The comparison method allowed analyzing the functioning of the hot water supply system before and after completed works. The economic analysis provided the ability to compare the functional aspects of solutions and to determine the preconditions, which lead to the opportunity to reduce costs of construction and operation of the hot water supply system.

\section{THE RESULTS OF THE RESEARCH AND THEIR ANALYSIS}

\section{A. The residential house in Lielirbes Street 19}

The residential house on Lielirbes Street 19, Riga, has five floors. There are four sections and a basement floor. The hot water supply system is a bottom distribution. The renovation of the hot water supply system bottom distribution was performed in February of 2014.

Diagrams were constructed to evaluate the dynamics of losses of heat energy and consumption of hot water. The columns reflect the heat consumption required for the 
preparation of hot water in megawatts (MWh) summed with hot water consumption in cubic meters $\left(\mathrm{m}^{3}\right)$.

Fig. 1 shows the consumption of heat energy. Green columns are the consumptions in year 2013, but blue - in 2014.

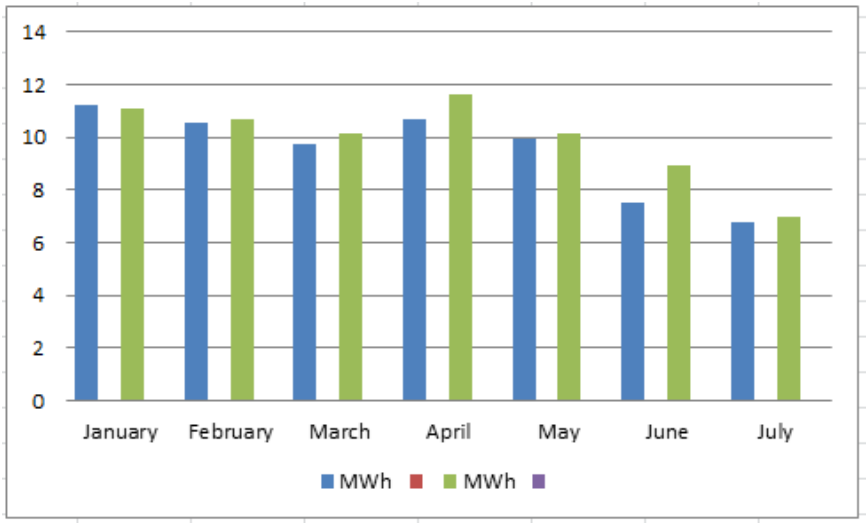

Fig. 1. Heat energy consumption for the preparation of hot water in years 2013 and 2014

Fig. 2 shows water consumption during the same time period.

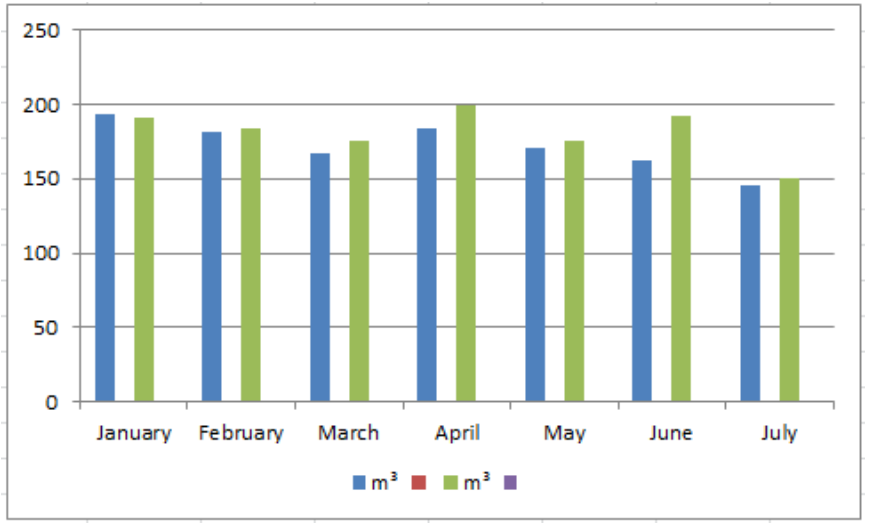

Fig. 2. Hot water consumption in 2013 and 2014.

The analysis of heat power consumption for the preparation of hot water for periods from January to July 2013 and January to July 2014 shows that it has increased by $4.69 \%$. Hot water consumption has the same dynamics and an increase equal to $4.97 \%$. Respectively, the average water consumption per person during the day has also changed; it was equal to 41.25 liters per day in 2013 and 43.41itrs liters per day in 2014.

Continuing the research of the situation allows drawing the conclusion that during winter / heating period the amount of heat energy required for the preparation of hot water and hot water consumption have both increased by $3.33 \%$, but during the summer period - accordingly by $6.95 \%$ and $7.35 \%$. $0.05815 \mathrm{MWh}$ were used to prepare $1 \mathrm{~m}^{3}$ of hot water during the winter / heating season in 2013, but $0.05067 \mathrm{MWh}-$ during the summer period of 2013. 0.05815 MWh were used to prepare $1 \mathrm{~m}^{3}$ of hot water during the winter / heating season in 2014, but $0.05046 \mathrm{MWh}$ - during the summer period of 2014. The average values are: $0.05518 \mathrm{MWh}$ in 2013 , and $0.05501 \mathrm{MWh}$ in 2014. It can be determined that the consumption of heat required to prepare $1 \mathrm{~m}^{3}$ of hot water has decreased by $0.30 \%$

\section{B. Residential house on Valdeku Street 66 k-1}

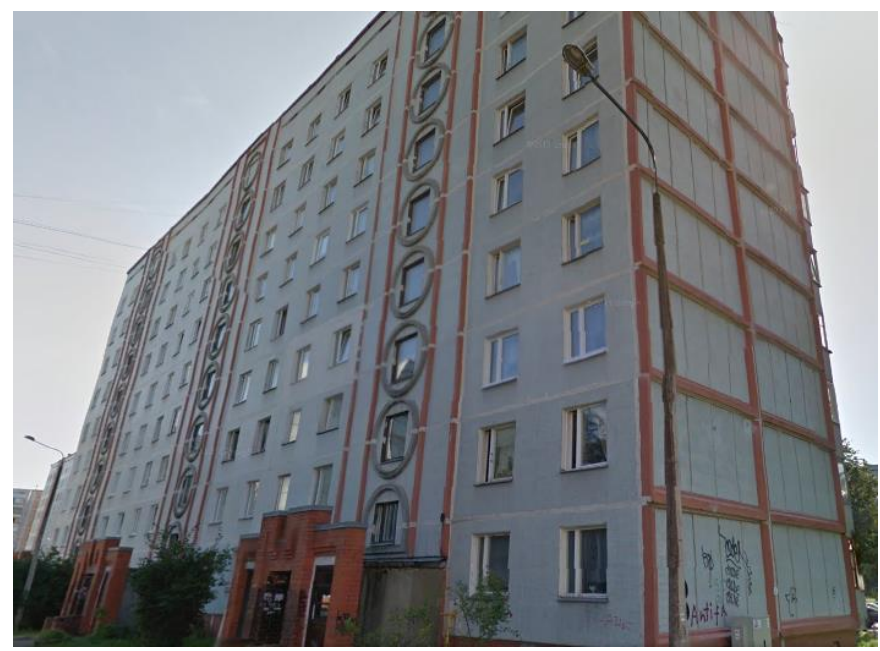

Fig. 3. Residential house in Valdeku Street 66 k-1 [7].

The residential house on Valdeku Street 66 k-1, Riga, belongs to the batch / series 602, having accordingly 9 floors and 3 sections (or staircases). The building has a basement and a ventilated attic. It also has a bottom distribution of hot water supply that was replaced in March of 2014.

Figures 4 and 5 include diagrams on the heat energy consumption required for the preparation of hot water and its consumption. The dark red columns correspond to the year 2013, but the light red - to year 2014 .

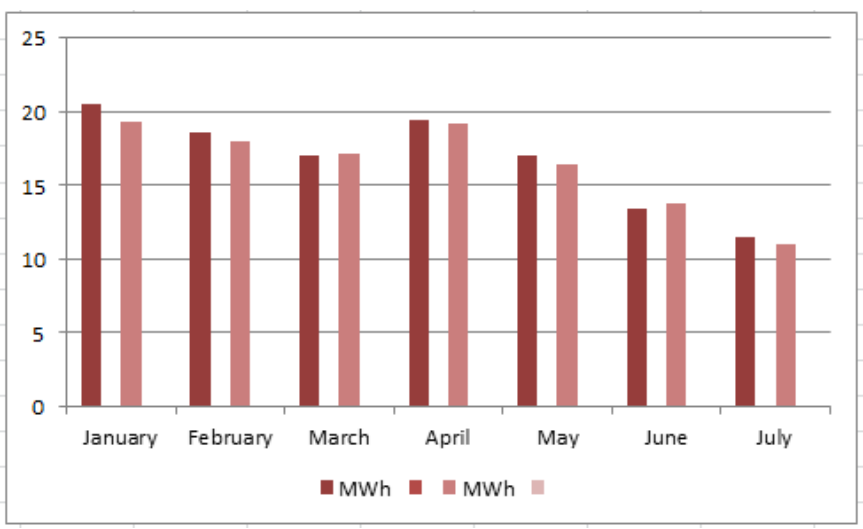

Fig. 4. Heat consumption required for the preparation of hot water in 2013 and 2014.

Analyzing the obtained data, it can be concluded that the average heat energy consumption has decreased by $2.09 \%$ in comparison with the year 2013, but hot water consumption dropped by $2.02 \%$ comparing with the same year. Observing hot water consumption trend, it can be seen that the consumption standard per person during the day has not 
generally changed, comprising 48.19 liters per day in 2013 , and 47.21 liters per day in 2014.

The review of the acquired data shows that heat energy consumption required for the preparation of hot water has reduced by $2.24 \%$ during the heating period in comparison with 2013 , as well as a reduction by $1.83 \%$ has been noticed during the summer period. The same dynamics is determined in the hot water consumption: during the heating period the consumption dropped by $2.23 \%$, but in the summer period by $1.69 \%$ in comparison with the year 2013 .

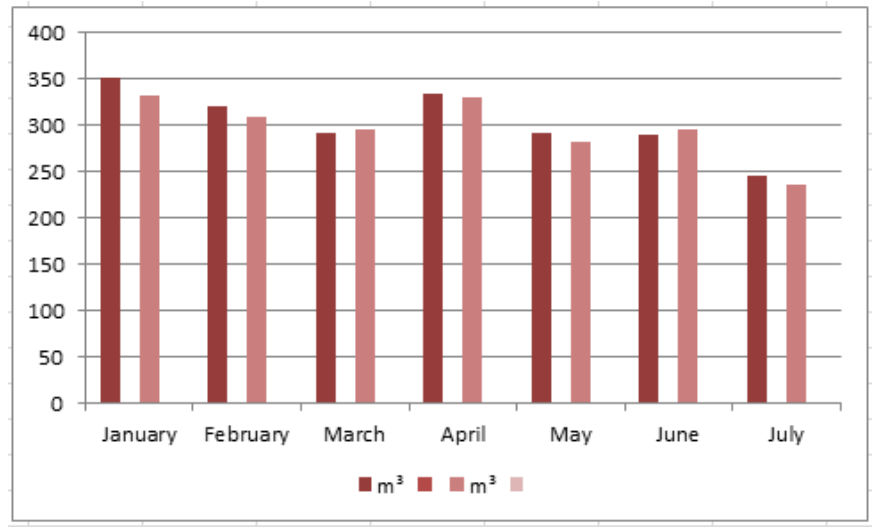

Fig. 5. Consumption of hot water in 2013 and 2014.

During the heating period of 2013, $0.05815 \mathrm{MWh}$ were required to prepare $1 \mathrm{~m}^{3}$ of hot water, during the summer period - 0.0563 MWh. In 2014 during the heating period $0.05815 \mathrm{MWh}$ and in summer period - $0.05056 \mathrm{MWh}$. Finally, the average values are $0.05464 \mathrm{MWh}$ in 2013, but $0.05462 \mathrm{MWh}$ in 2014. The initial reduction of the value is equal to $0.04 \%$ comparing to the year 2013 .

\section{Residential house on Valdeku Street 60 k-4}

The residential house on Valdeku Street 60 k-4, Riga, belongs to the batch / series 602, has 9 floors, 1 section. The building has a basement and a ventilated attic. The hot water supply system has a bottom distribution, which was replaced in April of 2014.

The diagrams in Figures 7 and 8 represent the heat energy consumption for the preparation of hot water and hot water consumption, where blue columns correspond to the year 2013, but green - to the year 2014.

Analyzing the obtained data, it can be concluded that the average heat energy consumption has increased by $8.95 \%$ in comparison with the year 2013, but hot water consumption also increased by $9.15 \%$ comparing with the same year. Observing hot water consumption trend. it can be seen that the consumption standard per person during the day has not generally changed, comprising 41.37 liters per day in 2013 , and 45.54 liters per day - in 2014.

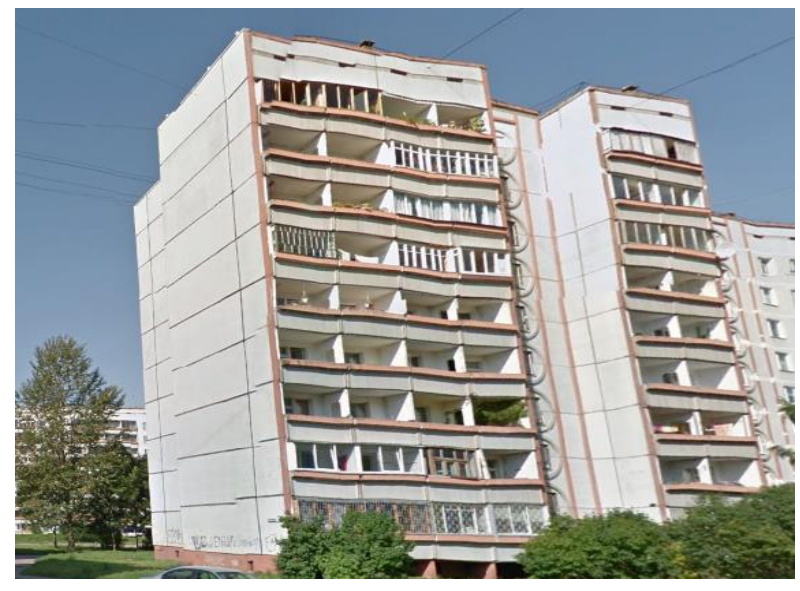

Fig. 6. Residential house on Valdeku Street 60 k-4, Riga [7].

During the heating period of 2013, $0.05815 \mathrm{MWh}$ were required to prepare $1 \mathrm{~m}^{3}$ of hot water, during the summer period - 0.0546 MWh. In 2014 during the heating period $0.05815 \mathrm{MWh}$ and in summer period - 0.05042 MWh. Finally, the average values are $0.05455 \mathrm{MWh}$ in 2013, but $0.05448 \mathrm{MWh}$ in 2014. The initial reduction of the value is equal to $0.12 \%$ comparing with the year 2013 .

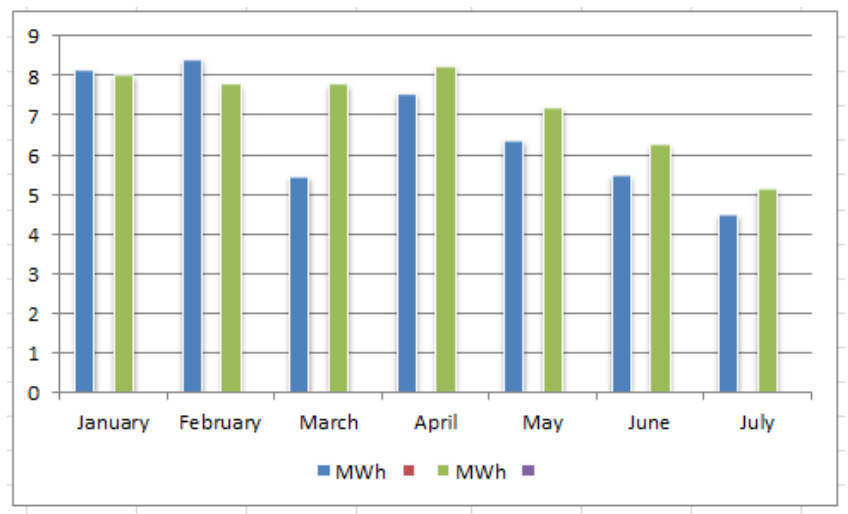

Fig. 7. Heat consumption required for the preparation of hot water in 2013 and 2014.

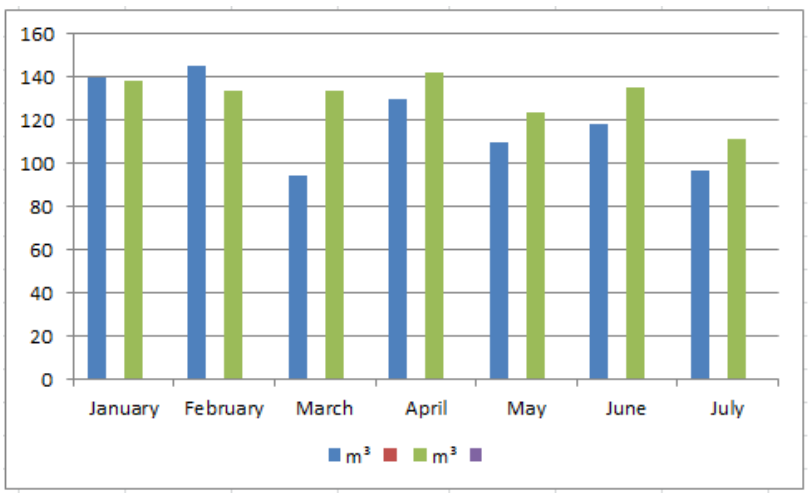

Fig. 8. Consumption of hot water in 2013 and 2014. 


\section{Residential house on Valdeku Street 51}

The residential house on Valdeku Street 51, Riga, belongs to the batch / series 119, has 2 sections, 10 floors with a basement and a ventilated attic. There is also bottom hot water distribution, replaced in April of 2014.

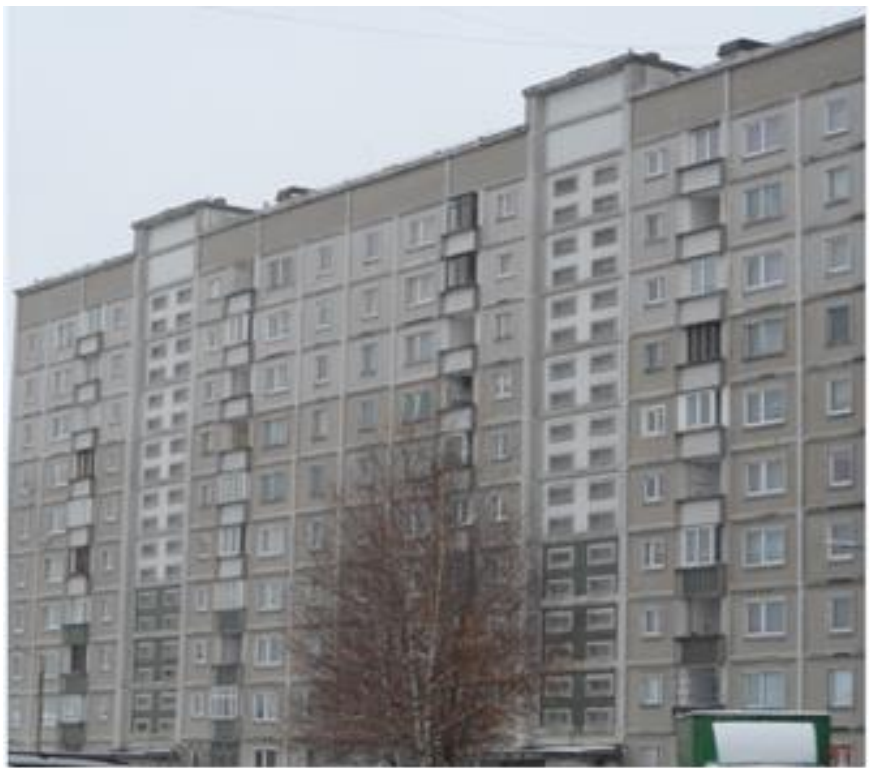

Fig. 9. Residential house on Valdeku Street 51, Riga [7]

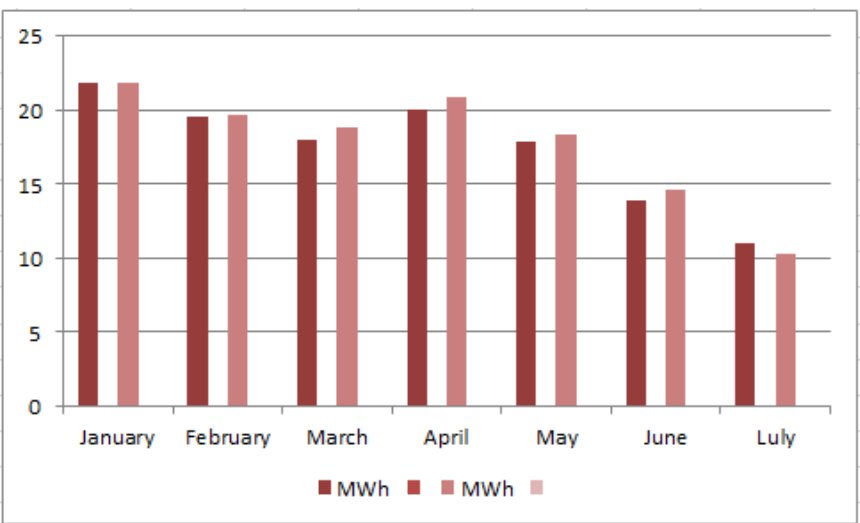

Fig. 10. Heat consumption required for the preparation of hot water in 2013 and 2014.

In Figures 10 and 11 heat energy consumption required for the preparation of hot water and the consumption of hot water are reflected, where the values in the year 2013 are indicated with dark red, but with light red - in the year 2014 .

The observation of the data shows that heat energy consumption and hot water have both increased in comparison with the year 2013 by $1.69 \%$ and $1.60 \%$ respectively.

The amount of heat energy required for the preparation of hot water has increased by $2.15 \%$ in the heating period and by $0.83 \%$ - in the summer period. The same trend describes hot water consumption in comparison with the year 2013 during the same seasons - by $2.15 \%$ and $0.71 \%$. Hot water consumption by a single person per day has also increased up to 50.62 liters per day in 2013 , and till 51.44 liters per day in 2014.

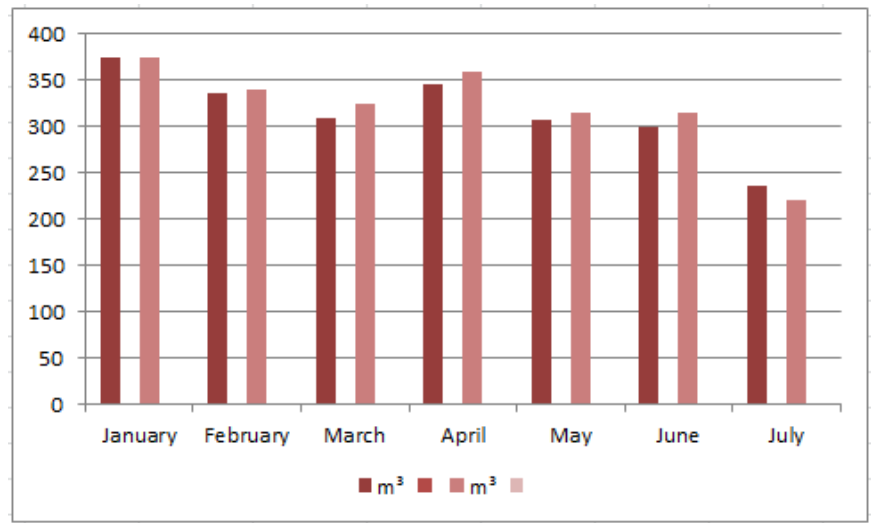

Fig. 11. Consumption of hot water in 2013 and 2014.

The average heat energy consumption during the heating period reached 0.05815 MWh during both 2013 and 2014, but in summer we see a considerable difference $-0.05077 \mathrm{MWh}$ and $0.05083 \mathrm{MWh}$. The drawn average of 2013 is equal to $0.05533 \mathrm{MWh}$, but in 2014 it reached $0.05538 \mathrm{MWh}-$ an increase by $0.09 \%$ has been determined.

\section{E. Residential house on Ozolciema Street 34}

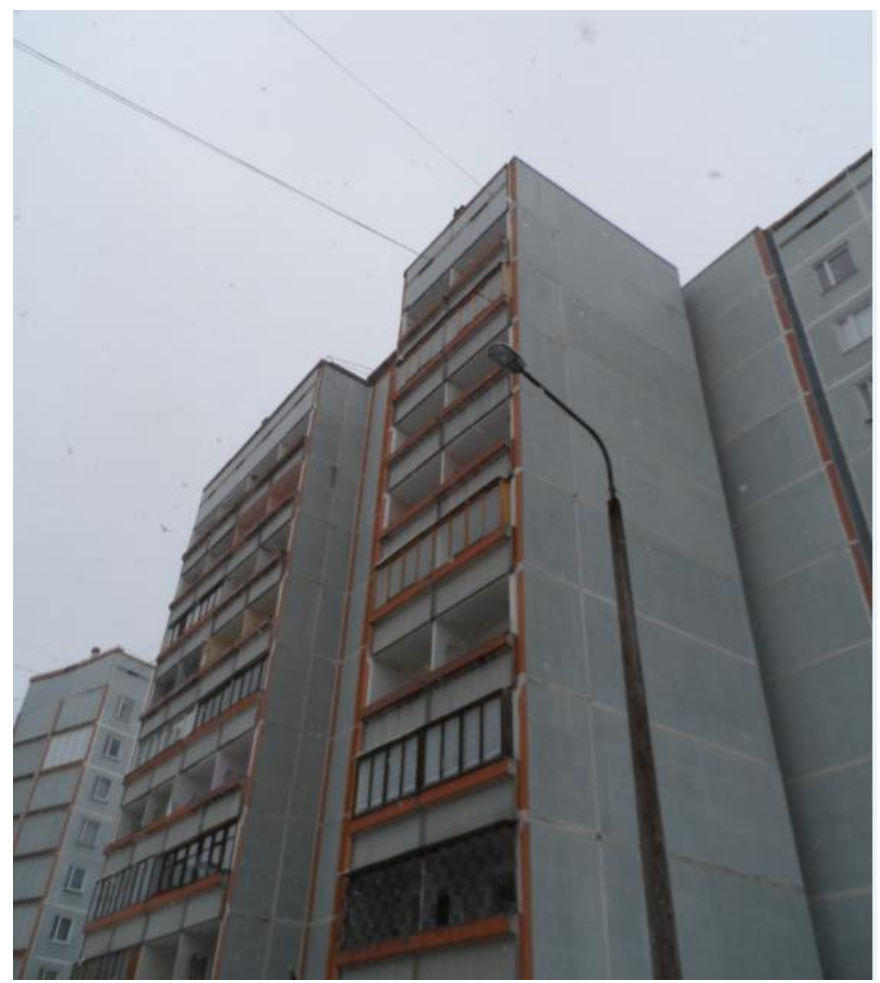

Fig. 12. Residential house on Ozolciema Street 34, Riga [7].

The residential house on Ozolciema Street 34, Riga, belongs to the batch / series 602. There are 9 floors, only 1 section, and a bottom hot water distribution system, which was replaced in April of 2014. 
Completing the analysis of the obtained data, the diagrams of heat energy consumption required for hot water preparation and hot water consumption were constructed (see Figures 13 and 14).

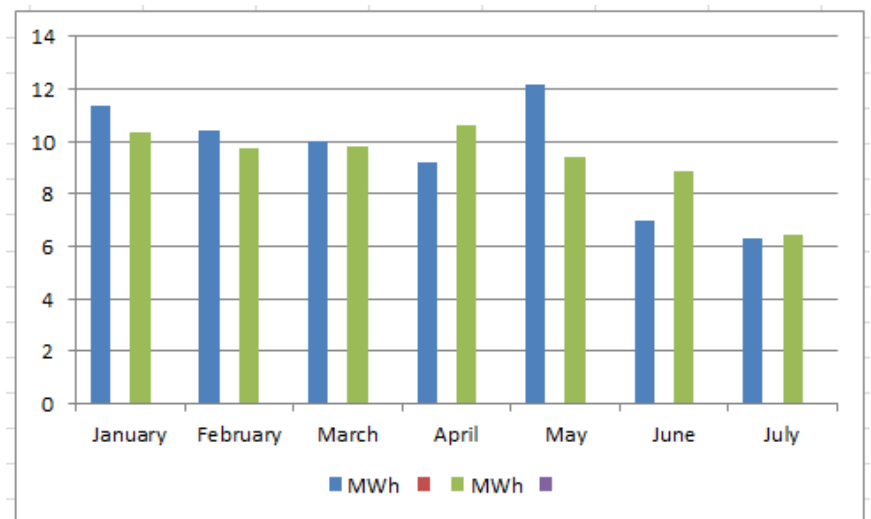

Fig. 13. Heat consumption required for the preparation of hot water in 2013 and 2014.

The analysis of the diagrams shows that the consumption of heat energy for the preparation of hot water as well as hot water consumption have both decreased in comparison with 2013 (the blue color is attached to the year 2013, but the green - to 2014 ) and was equal to $1.63 \%$ and $0.83 \%$.

Similar dynamics was observed in the heat energy consumption required for the preparation of hot water during both the heating and summer period that has decreased by $0.85 \%$ and $2.88 \%$. Hot water consumption has decreased by $0.85 \%$ during the heating period and by $0.81 \%$ - during the summer period, amounting to 60.69 liters per day per person in 2013 and 60.18 liters per day per person in 2014 .

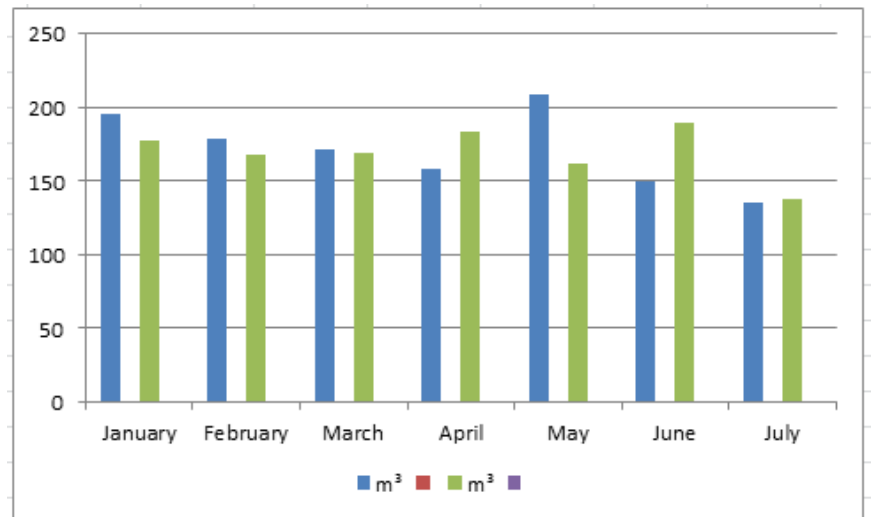

Fig. 14. Consumption of hot water in 2013 and 2014.

The analysis of the diagrams shows that the consumption of heat energy for the preparation of hot water as well as hot water consumption have both decreased in comparison with 2013 (the blue color is attached to the year 2013, but the green - to 2014) and was equal to $1.63 \%$ and $0.83 \%$.

Similar dynamics was observed in the consumption of heat energy required for the preparation of hot water during both the heating and summer period that has decreased by $0.85 \%$ and $2.88 \%$. Hot water consumption has decreased by $0.85 \%$ during the heating period and by $0.81 \%$ - during the summer period, being 60.69 liters per day per person in 2013 and 60.18 liters per day per person in 2014.

To prepare $1 \mathrm{~m}^{3}$ of hot water, $0.05815 \mathrm{MWh}$ were used during the heating period in 2013, the same amount required $0.05144 \mathrm{MWh}$ during the summer period. In 2014 the values were equal to $0.05815 \mathrm{MWh}$ and $0.05037 \mathrm{MWh}$, respectively. The average values are $0.05485 \mathrm{MWh}$ for 2013 and 0.05438 MWh for 2014 , which is by $0.86 \%$ less.

\section{F. Residential house on Vienibas Avenue 192 k-3}

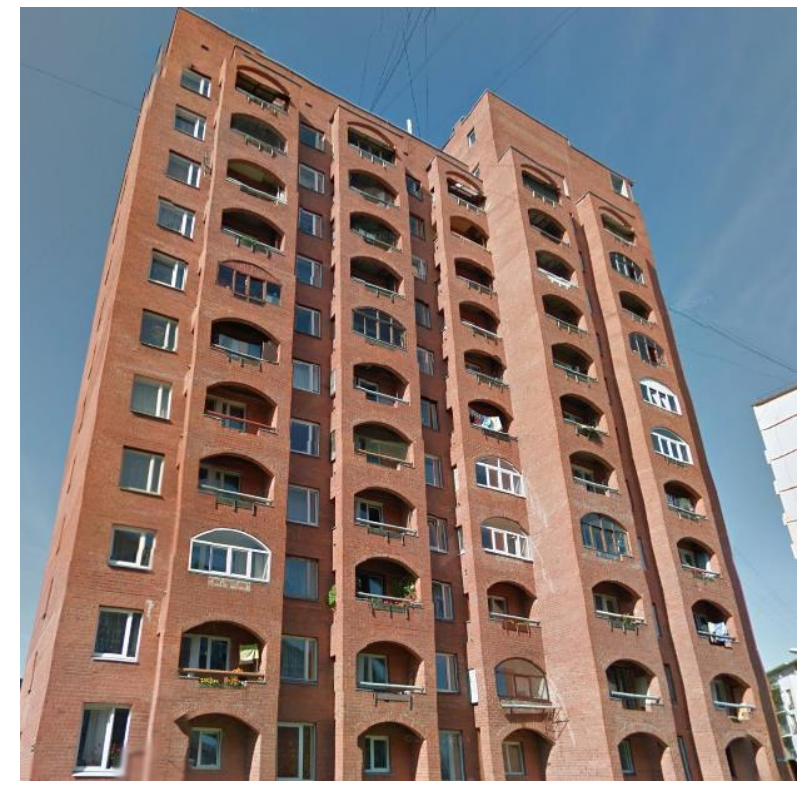

Fig. 15. Residential house on Vienibas Avenue 192 k-3 [7].

The residential house on Vienibas Avenue 192 k-3, Riga, has 11 floors and only 1 section. It is a modern building of a type that was not often constructed in Riga, but also has a bottom hot water distribution which required renovation and was replaced in February of the year 2014.

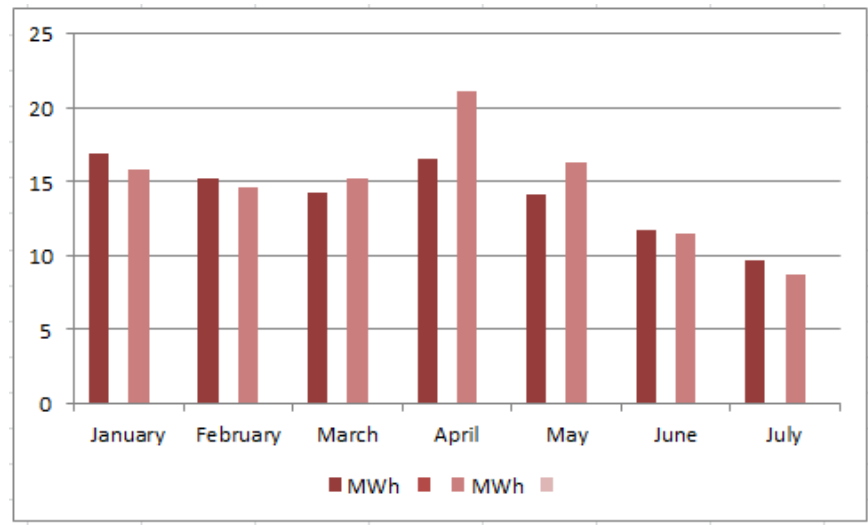

Fig. 16. Heat consumption required for the preparation of hot water in 2013 and 2014.

The same procedure of data analysis was used - all numbers acquired were projected in two diagrams - heat energy 
consumption required for the preparation of hot water and hot water consumption during the same periods, the two years 2013 (dark red columns) and 2014 (light red columns).

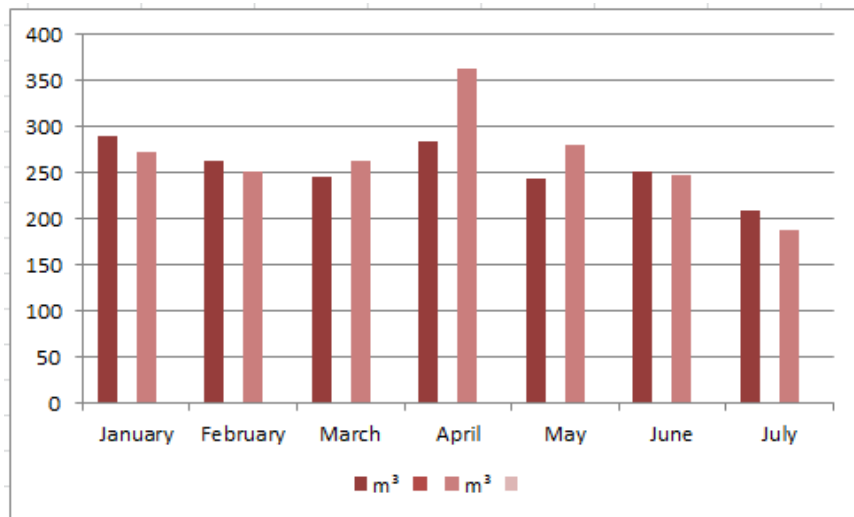

Fig. 17. Consumption of hot water in 2013 and 2014.

Both crucial values have increased in comparison with the reference year 2013: heat energy consumption by $4.72 \%$, but hot water consumption by $4.24 \%$. The trend was traced through the periods: the heating season brought an increase of $5.83 \%$ and the summer season $-2.68 \%$ for the heat energy, but only $5.83 \%$ and $1.68 \%$ - for the hot water consumption. As a matter of fact, the absolute value of the daily water consumption has also increased. During 2013 a person used 51.20 liters of hot water per day, but in 2014 - already 53.47 liters per day.

Analyzing the received data, we get closer to the initial aim - to determine heat energy consumption for the preparation of $1 \mathrm{~m}^{3}$ of hot water. $0.05815 \mathrm{WMh}$ were required during the heating period and $0.05056 \mathrm{MWh}$ during the summer period to complete the task in 2013. In 2014 this values were respectively $0.05815 \mathrm{MWh}$ and $0.05108 \mathrm{MWh}$. The average consumption in 2013 was $0.05458 \mathrm{MWh}$, slightly less than in $2014-0.05497$ MWh, by $0.72 \%$.

\section{DISCUSSION OF THE RESULTS}

The obtained results presented in the previous paragraphs were summarized for further research. The dynamics of both values is shown in relation with the objects used for the work.

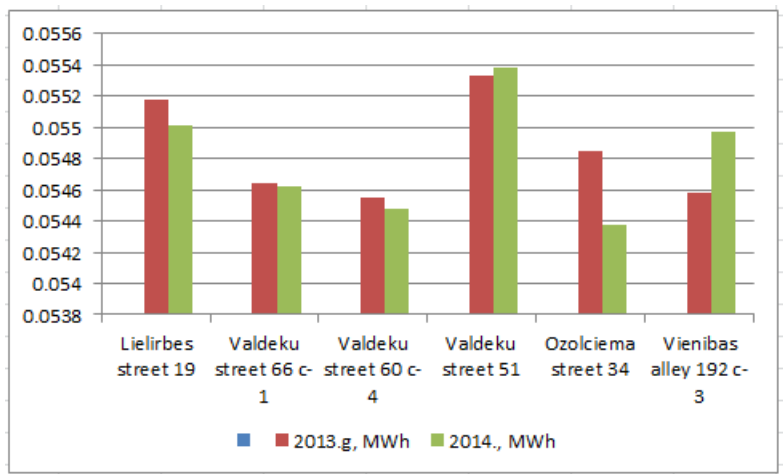

Fig. 18. Heat energy consumption for the preparation of $1 \mathrm{~m}^{3}$ of hot water.

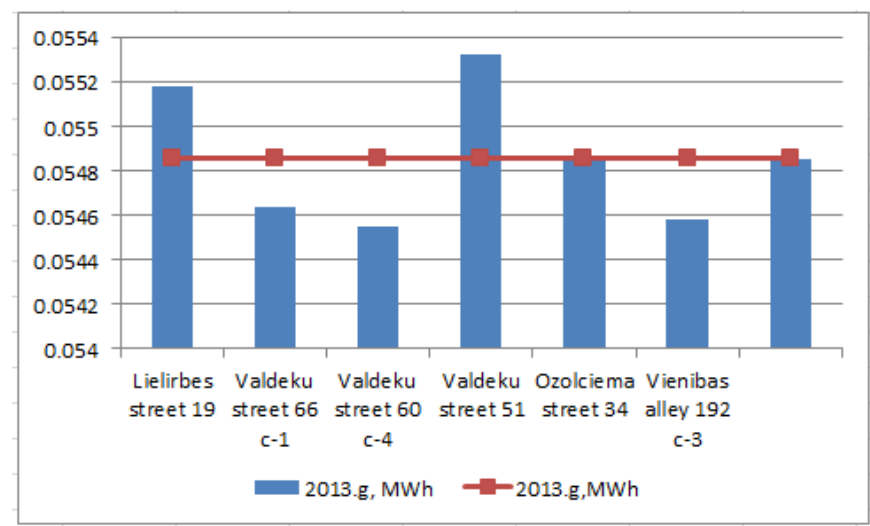

Fig. 19. Heat energy consumption for the preparation of $1 \mathrm{~m}^{3}$ of hot water in 2013.

In Fig. 18, heat energy consumption for the preparation of 1 $\mathrm{m}^{3}$ of hot water during both years is shown. Next two Figures - 19 and 20 - sum up the years 2013 and 2014 separately, with the average value equal to $0.05486 \mathrm{MWh}$ and 0.05481 MWh, accordingly.

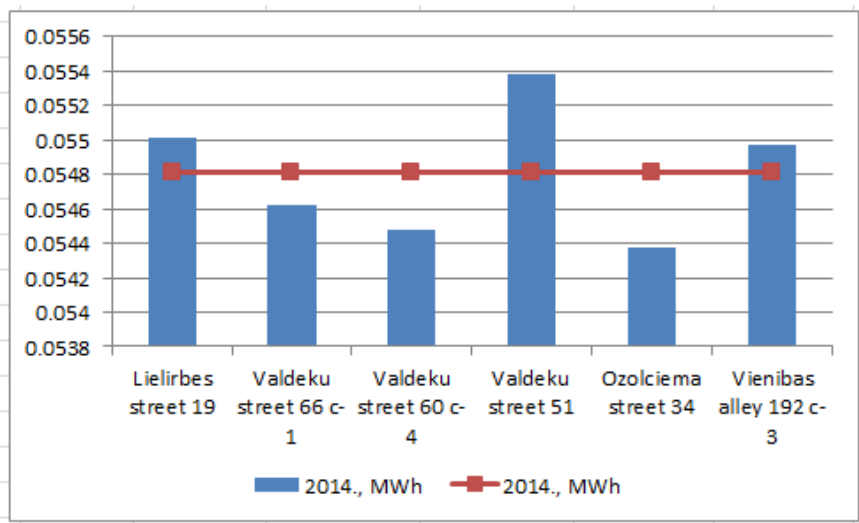

Fig. 20. Heat energy consumption for the preparation of $1 \mathrm{~m}^{3}$ of hot water in 2014.

Fig. 21 sums up the relative changes in the heat energy consumption required for the preparation of $1 \mathrm{~m}^{3}$ of hot water $(\%)$.

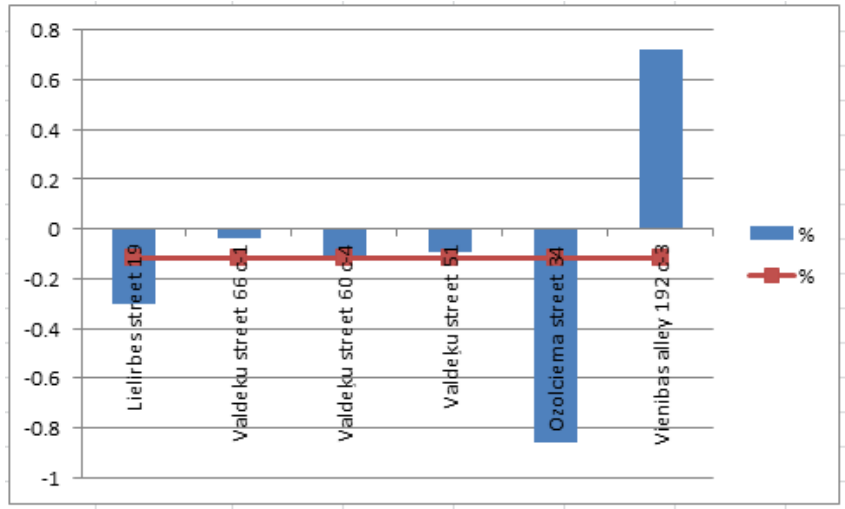

Fig. 21. The change in the values of heat energy consumption required for the preparation of $1 \mathrm{~m}^{3}$ of hot water in comparison with the year $2013(\%)$. 


\section{CONCLUSIONS}

Aggregated data analysis shows that:

1. In all of the residential buildings hot water consumption per person per day significantly differentiates from the regulatory values. During the year 2013, one person consumed an average of 48.89 liters per day or 1.47 cubic meters per month, during $2014-50.21$ liters per day or 1.51 cubic meters per month, as compared with the normative values (105 liters per day or 3.2 cubic meters per month). The determined values are almost twice as less as the planned ones.

2. The consumption of supplied thermal energy for hot water preparation increases on average by $2.33 \%$, but hot water consumption - by $2.44 \%$. The biggest heat energy consumption has been determined on Valdeku Street 60 $\mathrm{k}-4$, Riga, and is equal to $8.95 \%$, where hot water consumption also increased by $9.15 \%$ with the average of 45.54 liters per day per person. But the smallest increase is characteristic for the residential house on Ozolciema Street 34 , which is $1.63 \%$. Hot water consumption also increased by $0.83 \%$ with a bigger average consumption equal with 60.15 liters per day per person.

3 . The biggest heat energy consumption for the preparation of $1 \mathrm{~m}^{3}$ hot water has been determined in the residential house on Valdeku Street 51, Riga, which is equal to $0.05538 \mathrm{MWh}$, but the lowest has been noticed in the house on Ozolciema Street 34, Riga, which is equal to $0.05438 \mathrm{MWh}$.

4. Supplied thermal energy consumption for the preparation of $1 \mathrm{~m}^{3}$ hot water decreased by an average of $0.12 \%$ compared with the year 2013.

5. Replaced hot water supply system pipelines increased the temperature of hot water return, reaching $+43-+45^{\circ} \mathrm{C}$. It also allowed solving a secondary problem often found in district heating supply systems - the growth of Legionella pneumophila bacteria in the system significantly decreased.

6. The replacement of hot water supply system pipelines that were pushed to their limits and proved to be outdated according to the regulations allowed reducing the risk of accidents.

\section{REFERENCES}

[1] The Cabinet of Ministers of the Republic of Latvia. Regulations on Building Standard LBN $221-98$ „Buildings Internal Water Supply and Sewerage System". Latvijas Vēstnesis, 1998 (in Latvian).

[2] V. Shaflik Modern Hot Water Supply Systems. Kiev, 2010 (in Russian: Шафлик, В. Современные системы горячего водоснабжения. Киев: Таки справы, 2010).

[3] R. Ziemeḷnieks, T. Juhna, D. Birzniece, L. Mežule Occurrence of Legionellae in Hot Water Supply Systems of Riga City (in Latvian: Legionellas izplatība Rīgas karstā ūdens apgādes sistēmās // RTU zinātniskie raksti. 2. sēr., Būvzinātne, 6. sējums, 2005).

[4] Z. Budjko, V. Zebergs Investigation of the Domestic Hot Water Consumption in the Apartment Building. Publikācija izdevuma „RTU Zinātniskie raksti” sējumā, 2009.

[5] R. V. Shchekin, S. M. Korenevsky, G. E. Bem Handbook of Heat Supply and Ventilation. The Book One - Heating and Heat Supply (in Russian: Щекин, Р. В., Кореневский, С. М., Бем, Г. Е. Справочник по теплоснабжению ивентиляции. Книга первая - отопление и теплоснабжение. Киев: „Будівельник”,1976.)

[6] A. V. Khludov Hot Water Supply (in Russian: Хлудов, А. В. Горячее водоснабжение. Москва: Госсторйиздат, 1957.)

[7] Pictures are acquired from Googles Maps service or taken by Karina Tumanova. 